Ю^Аашев Т.У., А^ьджанова Н.К., Мұқан Н.

Имам әл-Мәтуридидің Аүниетанымы әлеуметтік алғышарттары

Toirshik Yuldashev, Nurlykhan Aljanova, Nurzat Mukan

\section{Socio-political background of the imam Al-Maturidi worldview's formation} қалыптасуының саяси-

Бұл мақалада имам Әбу Ханифа мұрасын жетілдіруші имам әлМатуридидің дүниетанымының қалыптасуы, оның саяси-әлеуметтік алғышарттары қарастырылады. Зерттеудің басты мақсаты - VIII-IX ғасырлар кезеңіндегі әл-Матуриди өмір сүрген ортасының саясиәлеуметтік жағдайы мен Аіни ахуалын та^дау, оның ислам теологиясына қосқан үлесін анықтау. Имам Матуридидің өмір сүрген кезеңі философиялық тұжырымдардың кеңеюі мен түрлі мәдени, саяси өзгерістермен тұспа-тұс келді. Тарихи, мәдени және этнос аралық оқиғалардың өрбуі исламның мәзһабтарға бөлінуіне әкелді. Осыған орай, Имам әл-Матуриди еңбектерін қазақ даласына тарату еліміздің ресми түрде қабылдаған діни жолын дәріптеп, исламды толық түсінуге бағыт-бағдар береді. Имам Матуридидің еңбектерін зерделей отырып, оның кәлам, мәзһабтар тарихы, фиққ әдістемесі мен тәпсір саласында өзіндік орны бар ірі ғалым екендігін пайымдауға болады. Мақалада ғалымның өмірі, ұстанымдары, ұстаздары мен шәкірттері жайында мәліметтер келтірілген. Сонымен қатар мұсылман әлемінің саяси өзгерістермен қатар географиялық ұлғаюы, ислами, шариғи түсініктердің бір жүйеге келтірілуі қажеттілігінің себептері, әл-Мәтуриди дүниетанымының қалыптасуының негізгі кезеңдері зерделенді.

Түйін сөздер: ислам, Матуриди, кәләм, фиқһ, ақида, сенім.

This article examines the formation of Imam al-Maturidi's ideology and its political-social background, of the successor of Abu Hanifa's heritage. The aim of this study is analyzing the religious situation and political-social environment in VIII-IX centuries al-Maturidi had lived. The life of Imam al-Maturidi coincided with a period of philosophical concepts enrichment and the various cultural, political changes. The development of historical and cultural events and inter-ethnic relations led to the emergence of madhhabs in Islam. In this regard, the dissemination of the Imam al-Maturidi's works in Kazakhstan contributes comprehension of a formally adopted by government Islamic school. Analyzing the works by Imam al-Maturidi, the important role of Imam al-Maturidi as an outstanding scientist in the field of Kalam, history of maddhabs, methodology, figh, and Tafsir may be noted. The article presents information about the life of the scientist, his philosophical positions, his mentors and followers. Also the geographic expansion of the Muslim community, systematization of Islamic Shariah concepts, the major periods of the Imam al-Maturidi's worldview formation are conceived.

Key words: Islam, Maturidi, Kalam, fiqh, aqeedah, faith.

Ю^Аашев Т.У., Альджанова Н.К., Мукан Н.

Социально-политические преАпосылки формирования мировоззрения имама Аль-Матуриди
В Аанной статье рассмотрено формирование мировоззрения, его политическо-социальных предпосылок имама аль-Матуриди, преемника наследия Абу ханифы. Целью Аанного исслеАования является анализирование религиозной ситуации и политическо-социальной среды VIII-IX вв., в которой жил аль-Матуриди. Жизнь имама альМатуриди совпала с периодом обогащении философских концепций и различных культурных, политических изменений. Развитие историко-культурных событий и межэтнических отношений привело к появлению мазхабов в исламе. В связи с этим, распространение трудов имама аль-Матуриди в Казахстане способствует осмыслению официально принятого государством школы ислама. Анализируя труды имама аль-Матуриди, можно отметить важную роль его в качестве выдающегося ученого в сфере калама, истории мазхабов, методомогии фикх и тафсир. В работе приведены данные о жизни ученого, его философской позиции, о его наставниках и последователей. Также осмысливаются географическое расширение мусульманской общины, причины необходимости систематизирования исламских, шариатских понятий, основные периоды формирования мировоззрения имама аль-Матуриди.

Ключевые слова: ислам, Матуриди, калам, фикх, акида, вера. 


\section{ИМАМ \\ ӘА-МӘТУРИАИАІН АҮНИЕТАНЫМЫ ҚААЫПТАСУЫНЫН САЯСИ-ӘАЕУМЕТТІК ААҒЫШАРТТАРЫ}

Әбу Мансұр Мұхаммад бин Мұхаммад бин Махмуд әлМәтуриди ас-Самарқанди тарих беттерінде ерекше орын алған Самарқанд қаласының Матурид елді мекенінде дүниеге келген. Оның нақты өмір сүрген жылы туралы деректер жоқ, бірақ кейбір тарихшылардың болжамы бойынша, ол хижра жыл санағына сай III ғ. аяғы мен IV ғ. басында әл-Мәтуриди Жағфар ибн әлМұғтасам халифтың кезеңінде өмір сүрген [1, 346 б.]. Имам әлМәтуриди Имам Ағзам әбу Ханифа қайтыс болғаннан кейін бір ғасырдан астам уақыт өткен соң, шамамен 259/870 жылы дүниеге келіп, 333/944 жылы Самарқанд қаласында дүние салды [2, 6 б.].

Имам Мәтуридидің шыққан тегі туралы тарихшылар екі түрлі көзқарас білдіреді. Олардың бірі, оны түркі тайпаларына жатқызса, енді бірі, ол түркі еліне ислам дінін дамыту мақсатында қоныстанған арабтар, яғни Мәдиналық әбу әйюб әл-Ансари әулетінен шыққан деп айтады.

Имам Мәтуридидің өмір сүрген кезеңі философиялық тұжырымдардың кеңеюі мен түрлі мәдени, саяси өзгерістермен тұспа тұс келеді. Ол Аббаси халифатында (кей деректерде «Бағдат халифаты» деп көрсетіледі) дүниеге келді. Аббаси әулеті 7501258 жылдары билік еткен, ислам әлеміндегі әділетті және Умәйя халифаттарынан кейінгі үшінші ірі мемлекет болды (1-сурет). Аббасилер исламның дамуына және күшеюіне зор үлес қосты.

Аббасидтердің халифы әли әл-Муктафи билігі кезінде оппозициялық бағытты ұстаған шииттер уақыт өте келе өзге мәдениеттер мен діндерге, антикалық, эллиндік философияға, әсіресе, ежелгі парсылық элементтерге тән ілімдерді сіңіріп өз ішінде бірнеше тармақтарға бөлінген. Сондай-ақ, шииттер ресми исламда жоқ идеялар мен дәстүрлі сунниттік теологияға қарсы пікір білдіріп отырған. 935 жылы шииттік бағыттағы парсы Буилер әулиеті Бағдатты басып, Аббаси әулетінен билікті тартып алды. Бірақ, кешегі күнгі халиф болған Аббаси әулиетінің өкілдері діни істерді өз қолдарында қалдырды. Бір империяға бағынған ислам діні, Аббаси халифаты әлсіреп, ыдырауы себебінен түрлі сенім бағыттарының белең алуына алып келді [4, 197 б.]. Сөйтіп, Аббаси халифатының жан-жағында тәуелсіз мемлекеттер пайда бола бастады. Тәуелсіздік жариялаған мемлекеттердің ішінде Самания, Иран, Хорасан, Систан және Саффариттер мемлекеттері пайда болды. 


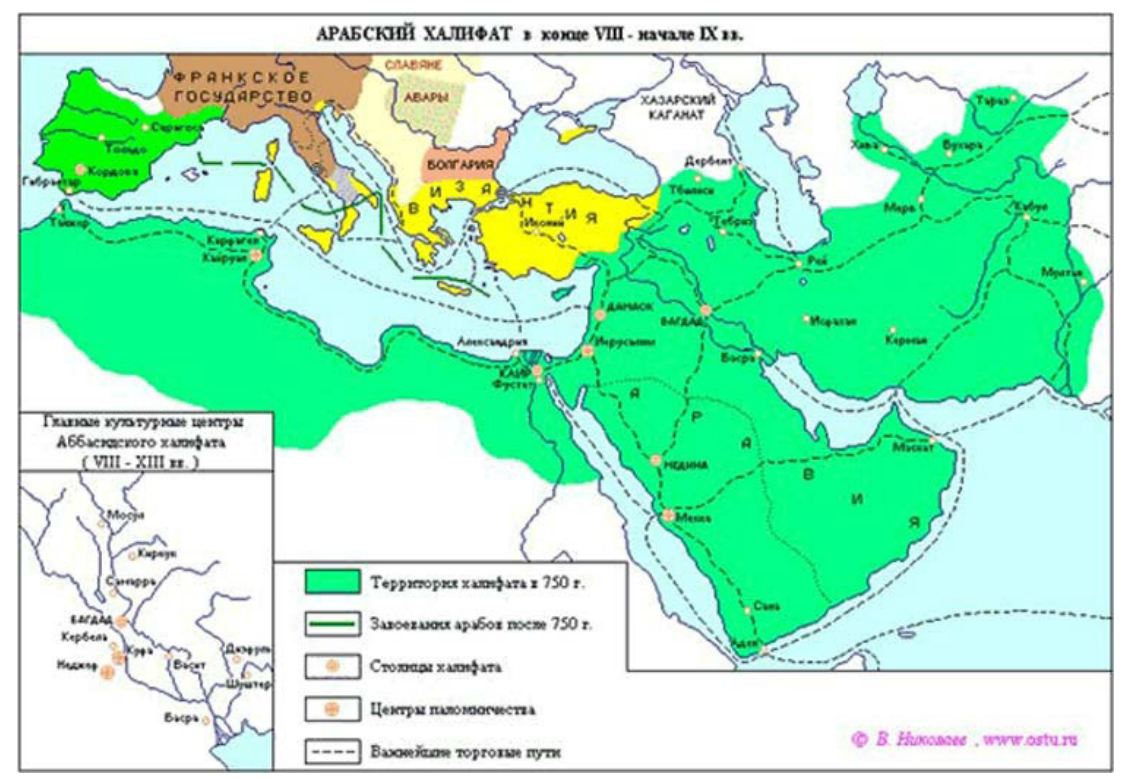

1-сурет - VIII ғ. аяғы мен IX ғ. басындағы Араб халифаты [3]

Самания мемлекеті имам Мәтуридидің өмір сүрген ортасы - Мәуереннаһрды, кейін 874999 жылдар арасында Иранды толық өз билігіне алды $[2,11$ б]. Саманидтер дәуірінде ғылым мен әдебиет дамыды, тіпті сарайларда ғалымдардың ортасы болды. Қалаларда, мешіттерде кітапханалар ашылды. Ең үлкен кітапхана - Мерв қаласында орналасты. Самания билеушілері ханафиттік ілімді қолдады.

Самания мемлекеті жайлы «Сияр ағлам әннубала» кітабында былай делінеді: «Самани отбасы парсы халықтарындағы тамыры терең шаңырақ». Бұл Харун Рашид халиф тұсында еді. Саманилер Асад ибн Саман ұрпақтары болған. Мәуереннаһрдың бір жағын Хорасанның әмірі басқарған еді [5, 291 б.].

Самания мемлекетінің тәуелсіздік жариялауындағы басты себеп Аббасилердің мемлекеті әлсіреуі болды. Аббасилер мемлекеті бірте-бірте әлсіреп, ислам үмметтері алдында абыройы жоғала бастады, сондықтан жан-жақтағы мемлекеттер өздерінің тәуелсіздігін жариялады. Аббасилердің билігінде тек қана Ирак, Парсы, Ахуаз қалғанымен елде бүлік шығарушылар көбейді. Көп ұзамай билік мәмлүк болған Даулами патшаға өтті [6, 450 б.].

Мұсылман әлемі саяси өзгерістермен қатар географиялық ұлғаюы ислами, шариғи түсініктердің бір жүйеге келтірілуі қажет болды. Ол келесі себептерге байланысты:

Ислам мемлекеттерінде саяси тұрақсыздық діни көзқарас айырмашылығын анық көрсетті.
Аббасихалифатына қарасты елдердің дүниетанымы әртүрлі болғандықтан, исламда хариджиттер, мурджииттер, мұғтазалиттер, каррамиттер деген сияқты ағымдар пайда бола бастады [7, 79 б.]. Олар Құранды өздігінше түсініп, өздерінің шынайылығы мен айрықшалықтарына сенді.

Халифа Мәмүн кезінде ежелгі грек философиясы араб тіліне аударылуы натуралистік, дахрилік, софистік, перипатетиктік философия өкілдері мәселені философиялық тұрғыда қарастыру ұсынылды. Ислам теологиясында әлемнің жаралуы, Құдай, Құдайдың мәні, пайғамбарлық, о дүние т.б. тақырыптарды тартыс алаңына енгізіп, оны күн тәртібіне айналдырды [2, 19 б.].

Араб халифатын құрған территорияда ислам діні таралмас бұрын зорастризм, манихейлік, христиандық, иудейлік, буддизм және тәңіршілдік сенімінің болуы $[8,10$ б.].

Осы аталған фактор мұсылмандардың санасына күмән ұялатқандықтан, ислам дінін сүннеттік бағытта түсіндіру қажеттілігі туындады. Ол ислам дінін иман негіздеріне қатысты мәселелерді бекіткен «Кәләм» (сенім) ілімін қалаушы Имам әл Матуриди мен әбул Хасан Ашғари сияқты көрнекті ғалымдардың келуіне жол ашты. Олардың ілімі Мұхаммед пайғамбардың (оған Алланың игілігі мен сәлемі болсын) ұстанған жолында, нақыл мен ақылға (Құран, хадис және ақыл) қайшы емес, әһли сүннет уәл-жамағат ағымы негізінде болса, ақида бойынша имам әл Мәтуриди - ханафи мазхабын, 
имам әл-Ашғари - малики, шафиғи мазхабтарын дәріптеді. Осылайша екі имам өз сенім мектептерін құрып, оларға ерушілер сенімде «матуридилер», «ашғарилер» деп бөлінді. Дегенмен, олардың еңбектерінен болмашы мәселелерде ғана 20-ға жетпес сөздік ерекшеліктерге қатысты айырмашылықтар бар екені байқалды [8, 11 б.]. Имам Мәтуриди өз шығармаларында имам Ағзамның мынандай кітаптарын қолданғандығын анықтаған: «әл-Фыкһул-әкбар», «әл-Фыкһул-әбсат», «Рисалату әбу Ханифа ила Осман әл-Ветти», «Ваиету әбу Ханифа ли-тилмизихи Юсуф б. Халид әс-Семти». Осы себептен де, зерттеушілер екі ғұламаны бір-бірінен ажыратып жатпайды [9].

Зерттеуші Захид әл-Кәусари «ИшаратулМарам» атты шығармасының кіріспесінде былай дейді: «Мәуреннаһр өлкесі бидғат пен бұзықтықтан алыс бір өлке еді. Мұндағылар сүннетті берік ұстанатын. Бұл жерлерде хадистер ұрпақтан ұрпаққа мұра ретінде қалдырылатын. Алайда, имам Мәтуриди деген ғалым шығып, ол әрбір мәселеге өзінше дәлелдер келтіре бастады. Ол, шариғатты негізге ала отырып, ақылмен де үкім беретін».

Имам әл Мәтуриди сеніміне ерушілер Мәуереннаһрда, ал имам әл-Ашғариға Хорасан, Ирак, Шам, Египет, Магриб сияқты ислам мемлекеттері болды $[8,8$ б.].

Ислам мемлекеттері саяси бүлікке қарамастан имам әл-Мәтуриди өмір сүрген орта бейбіт, яғни бүліктен алыс болды.

Ислам дінінің мұсылмандарға жүктеген басты міндеттерінің бірі - білім алу екені мәлім. Осы себептен, Шығыс ілімге көп көңіл бөліп, білім деңгейін жоғарылатты. Шығыс елі ғұламалары көп, жақсылық ортасы, ілім жүйеленген, ислам үкімдері амалда көрінген, әскерлері батыр, халқы жаужүрек, ойлары кемел, ғалымдары патшалары сияқты, құл болғандар патшалыққа дейін жеткендер болды [10, 360 б.].

Ел басшылары әр жылы рамазан айында ғұламаларын жинап, сұрақ қойып, қоғам үшін пайдалы мәселелерді талқылайтын. Олардың барлығы Ханафи мазхабын ұстанатын еді [10, 338-339 бб.].

«Уафиятул ағян» атты кітапта әл-Мәтуриди өскен Самания мемлекеті жайлы былай дейді: «Патшалары ғұламаларды «ілімнің сұлтандары» деп айтылатын. Ол мемлекетте әділдік, дін және ілім бірінші тұратын еді» - деп жазылған [11].

Араб жазушысы әрі тарихшысы әл-Мақдиси өз еңбегінде «Бұл өлкенің ғалымдары ғылым-білімнің шырқау шыңына қол жеткізген.
Ол жер - оқу-білім мен жақсылықтың қазынасы, исламның алынбас биік қамалы. Бұл жерде шариғат ғалымдары патшалардай сыйлы» деген сөздер келтіреді.

Ғылымның жаңғыруының себебі - патшадан бастап жай адамға дейін ілімді арттыруға әрекет еткен, кемінде әдебиетпен шұғылданған [4, 322 б]. Қоғамда көптеген ғұламалар шығып, олардың басында имам әбу Мансур әл-Мәтуриди тұрды. Сондай-ақ, хадис, фиқһ, тәпсір ілімдерінің ғұламалары шықты. Олар ілім алуда сабырлылық танытып, көптеген жерлерге барып ілім үйренді. Олардың бірі - ислам әлеміне әйгілі болған әбу Абдулла Мұхаммад ибн Исмаил әл-Бухари. Ол орталық Азиядан, Ирак, Шам, Хижазға барып ілім алады. Хадисті санад мәтінімен жаттап жинайды. Сол сияқты ислам әлеміндегі құнды деп саналатын кітабымен әйгілі - Муслим ибн Хажжаж ән-нисабури Сахих Муслимді атап кетпеуге болмайды. Олардың бәрі әл-Мәтуриди шыққан өлкеден болды.

Фиқһ (шариғат үкімдері) ілімінен көптеген ғұламалар шықты, тіпті, мужтахид (пәтуа бере алатын ғалым) ғалымдар болды. Әбу Хатим Мұхаммад ибн Хиббан әс-Самарқанди, Бурханиддин әл-Марғинани, әбу Ләйс әс-Самарқанди сияқты тағы басқа сол өңірден шыққан ғұламаларды айтуға болады.

Осы кезеңде сопылық бағытын дәріптеген ғалымдар да көп болған. Мәселен, әйгілі сопы, ғалым Хорасанның машайхтарынан шыққан - Шақиқ әл-Балхи (153 хижри жылы қайтыс болған). Ол Хорасанда бірінші болып хал ілімін қозғаған ғұлама деп саналады [12, 106 б.].

Шығыс елдерінде білім-ғылымның дамуы - бүкіл адамзат өміріне маңызды ғылыми жаңалықтар енгізгені және Шығыстың ғылыми құндылықтарға әлем бойынша алғаш болып есік ашқаны, тарих беттерінде анық жазылған.

Жоғарыда көрсеткен дін ғұламаларынан басқа философия, метафизика, астрономия, математка, музыка, медицина салаларында елеулі орын алған, екінші ұстаз - әбу Насыр әлФараби және медицина ғылымының атасы - әбу әли ибн Сина сынды ғалымдар осы өңірден шығып, әлемдік ғылым салаларына өшпестей орын қалдырды.

Осыдан кейн бізге Ұлы Имам әбу Мансур әл-Мәтуриди заманының қандай болғаны айқындалады. Бұл жетістіктер төмендегі себептерге байланысты:

Самани патшаларының ғұламаларға болған құрметі, оларға берілетін жоғарғы орын ғұламалар көбеюіне себеп болды; 
Бейбіт өмір, жайлы ғұмыр, тұрақтылықтың себебімен ақыл дамып, ғылыми идеялар пайда болып, ілім артты;

Ғылыми кеңестердің жиі-жиі болуы, жыл сайын рамазан айында патшаның тапсырмасымен ғұламалар жиналып, ғылыми пікір алысты және діни фәтуалар тағы басқа мәселелер қарастырды. Әрбір ғұлама ең абзал дәлелді ұсынуға әрекет етті. Осының әсерінен қоғамда көп ізденушілер мен білім арттырушылар көбейді;

әртүрлі мәзхабтардың пайда болуы фиқһтың нығаюына әкелді. Әр түрлі мазһаб ұстанушы өзінің мазһабын үстем етуге әрекет етіп көп ізденетін болған;

Мәуреннаһр шаһар тұрғындардың көп шоғырланған аймағы болумен қоса, ол жер саудасаттық орталығы болғандықтан, басқа діни конфессиялар өкілдері мекендеген;

Аббасилердің басқару кезеңінің жалпы ғылымға көңіл бөлінді, тіпті дуализмді қуаттайтын ежелгі зороастизм мен монотеистикалық сенім жүйесін ұстанатындар да болды. Ежелден дуализмге, яғни екі құдайға (жақсылық жасаушы құдай мен жаманшылық жасаушы құдай) сенген парсылар мен соғдырлар Мәуреннаһр мұсылмандарымен араласып өмір сүрді. Сондықтан Мұхаммед пайғамбардан (оған Алланың игілігі мен сәлемі болсын) тараған хадистерді жинақтау, Құран тәпсірі мен фиқһ ілімдерін ел арасында дамыту басты мақсат болды. Дуализмге қарсы жауап қайтарушы кәлами ғалымдар көбейе бастады.

Баршаға белгілі болғандай әр заманда әртүрлі діндер, әртүрлі ағымдар болған. Әрбір ағым мүшесі өзін тура жолдамын деп есептеген. Бұл көрініс әл-Мәтуриди заманында да орын алды. Ол дәуірде мұсылман қоғамымен бірге христиандар мен яхудилер де болғанын білеміз. Мұсылмандар басқа дін өкілдеріне сабырлықпен, қазіргі тілмен айтқанда толерантты мінез танытқан. Тіпті, мұсылман халифатының орталығы Бағдад қаласында христиандар мен яхудилер өмір сүргенін тарих растайды. Христиандар мен яхудилер өздерінің діни мейрамдары мен құлшылықтарын Бағдад қаласының сыртында орындайтын болған. Аббаси халифтері басқа діндерге көрсеткен кеңшілігінің себебін Құран аятымен түсіндіруге болады. Мәселен Құранда Жаратушы былай дейді:

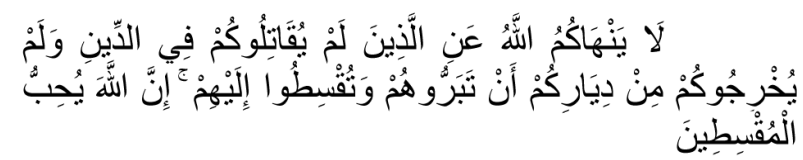

«Алла (Т.) дінжайында сендермен совыспаван және жұрттарыңнан шыгармавандарга жақсыллық қылуларыңа, дділдік етулеріңе тыйылм салмайды. Расында Алла (Т.) турашылдарды жақсы көреді» [13, 462 б]. Және тағы басқа аятта:

$$
\text { لَكَمْ دِينْكُمْ وَلِِيَ دِينِ }
$$

«Сендердің діндерің өздеріңе, менің дінім өзіме тән» де», - деп айтылған [13, 657 б]. Бұл екі аятты жақсы түсінген мұсылман қоғамы басқа діндерге қарсы шықпайды, керісінше, Алла тағала айтқандай жақсылық жасап, әділдік етеді. Егер мұсылман ғұламалары басқа дін өкілдерімен діни мәселелерге қатысты дауласатын болса, іліммен сабырлылықпен және әділділікпен дауласты. Өйткені мұсылман адам солай тәрбиелі болуға бұйырылған. Кұранда былай айтылады:

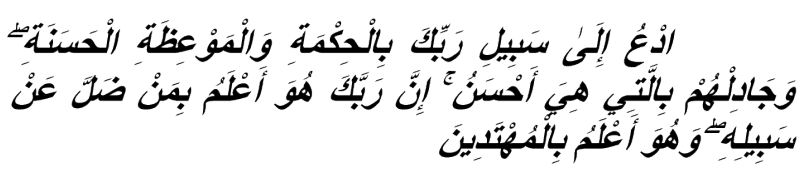

«Адамдарды Раббыңның жольнда данальққ және көркем үгіт арқылы шақыр. Әрі олармен көркем түрде күрес. Күдіксіз, Раббың Ол, тура жол тапқ̧андарды да жақссы біледі» [13, 327 б.]. Бұл аятпен белгілі болғандай егер мұсылманның білімі саяз болатын болса, басқаларға уағыз айтылуы тыйым салынады және уағыз айту, хақ жолға шақыру тек мұсылман ғұламаларына ғана тән сипат деуге болады. Өйткені Жаратушы «Раббыңның жолына даналықпен шақыр» деп бұйырған. Адамның білімі аз болатын болса, оның бойында қателіктер көп табылады. Дана болу үшін әрине ілім керек. Даналықты жақсы білгендер тек ғұламалар болып табылады. Сонымен қатар, Алла тағала сөзінде «әрі олармен (басқза діндегілермен) көркем түрде күрес» деп баяндайды. Аяттан мәлім өзге дін иелерімен сыпайы болу, тіпті, ілім жолында дауласатын уақытта да көркем түрде, әдеп-ахлақпен, екі жақ бір-бірін құрметтеген хәлде болуын талап етеді.

Әл-Мәтуриди дүниетанымының қалыптасуы мынадай негізгі төрт кезеңнен тұрады:

Бірінші кезең оның өскен жері мен қоршаған ортасына байланысты. Имам Матуриди өскен орта исламның дамуы жолымен тығыз байланысты болғандықтан, қоғам нақты діни ұстанымдардың бекуін күтті;

Екінші кезең - аяққа тұру, дамуы немесе мазһабтың құрылуы. Жалпы алғанда, Имам Мату- 
ридидің ұстаздары ретінде Ханафи ғұламалары әбу Бәкір Ахмад бин Исхақ бин Салих әл-Жузжаниді, әбу Наср Ахмад бин әл-Аббас әл-Иязиді, Мухаммад бин Муқатил ар-Разиді, Нусейр бин Яхя әл-Балхиді, әбу Бәкір Мухаммад бин Ахмад Ража әл-Жузжаниді атауға болады [14, 41-43 б]. Мәтуриди сенімі ілімінің дамуына оның шәкірттері себеп болды. Әл-Мәтуридидің ең атақты шәкірті - әбу Қасым Исхақ ибн Мұхаммад әл-Хәким әс-Самарқанди (342 хижра жылы бойынша). Ол «әл-Хәким» (ақылды, данышпан) деген атпен әйгілі. Ханафи мазһабының ұлы шейхы болып есептелетін - әбу Мұхаммад Иса әл-Баздауи (390 хижра жылы бойынша) және т.б.;

Үшінші кезең - әбу Мансур әл-Мәтуридидің еңбектерінің, дәлелдерінің ілім болып қалыптасуы. Сенім мектебінің дамуының бірден бір себебі шәкірттерінің сенім мазһабын дамытуына қосқан еңбектері деп айта аламыз;

Төртінші кезең - әл-Мәтуриди сенімінің таралуы. 700-1300 хижри жылдарда Имам әлМәтуридидің сенім бағыты белсенді дамыды. Осман империясының сұлтандары әл-Мәтуриди сенім бағытын ұстанды. Осман империясының кеңеюімен әл-Мәтуриди сенім мектебі де дамып отырды. Жердің шығысы мен батысы, арабтар мен үнділер, парсылар мен түркілер және орталық Азия әл-Мәтуриди сенім бағытында болды.

Әбу Хасан ән-Надауи өзінің «Рижәл әлфикр уә әд-дағуа» атты еңбегінде имам Мәтуриди туралы былай дейді: «Адамдардың ой тұрғысынан жетпеген жетістіктеріне жеткен, толыққанды ақылды, көптеген ғылымды меңгерген тұлға» [15].

Бұхара орталық болғанымен, Самарқанд шаһарының халқы тығыз орналасқан мәдени мекен болды. Оның үстіне сауда керуені жүріп өтетін Ұлы Жібек Жолы бойында орналасқандықтан, түрлі діндер мен мәдениет өкілдері жиі кездесетін орта қалыптасты. Осының әсерінен, мәзһабаралық пікірталастар кеңінен етек алып, қызу тартыстар жүргізілетін [16, 278 б]. Саманидтер әулеті ислам дініне қатысты ғылыми-зерттеу жұмыстарының дұрыс жолға қойылуы үшін дін ғылымы иелерін әрдайым қолдап отырды. Әли әл-Муктафидің басшылығы кезінде каррамилер (карамиттер) күшейе бастаған болатын. Каррамилер - шейіттерден шыққан ислам атын жамылған сектанттар тобы. Олар IX ғасырда Аббаси халифатында көтерілістер жасады. Сондай-ақ, Мәуреннаһрдың Хорасаннан басқа аймақтарында мұғтазилиттердің сенімге байланысты көзқарастары кеңі- нен тараған еді. Осы себептерге байланысты имам әл-Мәтуриди каррамилер, шииттер және мұғтазилиттердің діни сеніміне келіспейтін тұстарын ашық айтып, пікірталастарға қатысып отыратын. Имам әл-Мәтуриди мұғтазилиттердің сеніміне бағытталған «Бәйану уәһмил мұғтазиләт» атты шығармасын арнады. Имам әл-Мәтуриди Самарқанд пен одан ары жатқан мемлекеттердегі пікір додаларына қатысып, көбіне сәттілікпен аяқтап отырды.

Дін ғалымдары ислам әлемін шарлап Пайғамбарымыздың (оған Алланың игілігі мен сәлемі болсын) хадистерін бір жерге жинаған. Мәуреннаһр аймағынан көрнекті де, данышпан имамдармен қатар «Кутуби Ситта», яғни, ең сенімді деп табылған 6 хадис жинағы шықты.

Имам Мәтуриди ислам шариғатын дұрыс түсіндіру үшін ақыл-ойға сүйену керектігін алға тартты. Бұл жағынан алғанда, ол діни мәтіндерді тек тура мағынасында түсінуді құптайтын кейбір ғұламалардың әдістемесінен басқаша жолды ұстанды. Мәселен, «Ақыл-ойдың жаңылуы мүмкін, сондықтан нақылды (Құран аяты мен хадисті) тек сөзбе-сөз түсіну керек» деген пікірдің иелеріне Мәтуриди «Китабу-т Таухид» атты еңбегінде: «...Бұл пікір (ақылмен ойлаудан қашу) - шайтанның қатерлі тұзақтарының біpi. Өйткені ақылды қолдануға қарсы келушілердің өздері ұстанымдарын ақтайтын ақылдан басқа ешқандай дәлел келтіре алмайды (олар осы қарсылықтарының өзінде ақылға жүгініп отыр). Мұның өзі оларға ақылмен ойлаудың аса зәрулігін мойындатуға жеткілікті. Олар қалайша ақылға салып ойлауды жоққа шығарады. Алла Тағала құлдарын ойлауға шақырады, оларға ой топшылау мен ақыл ізденісін жасауды бұйырады, сол арқылы ғибрат пен үгіт-насихат алудың қажеттілігін көрсетеді. Асылында ой-пікір мен ақылға салу ғылымның қайнар көздерінің бірі екендігін дәлелдейді» деп, нақты әрі қисынды тұжырымдарын алға тартады. Ақылға сүйенгенде де шариғат шеңберінен шығып кетпеу имам Матуридидің ұстанымы болған [17, 247 б.].

Өз дәуірінің кемеңгер ойшылы және теологы әбу Мансур әл-Мәтуриди артына қалдырған еңбектерінің қатарын Құран Кәрімнің тәпсірі болған «Китабу Тәуилати әһли Сунна» (немесе «Тәуилату-л Қуран») бастайды. Имам Мәтуриди «Алланы тануда ақыл маңызды рөл атқарады» деп есептегенмен, исламдағы көптеген үкімдердің сырын ұғынуға тек ақылдың күші жетпейтінін мойындайды. Мұндай жағдайда, Алланың жәрдеміне сүйене отырып, «үкімдердің мәнін ұғынуға тура келеді» деп пайымдайды. 
Имам Мәтуриди болмыстағы кейбір нәрселердің бойында жамандықтың (кувһ-зат) болғанын және ақылды кейбір нәрселердегі жақсы мен жаманды айыра алады деп түсінді. Себебі, жақсыны пайымдай алатын да, жамандықты айыра алатын да және жақсы мен жаманды айыра алмайтын да - ақыл. Имам Мәтуридидің бұл көзқарасы бір қарағанда муғтазалиттердің ұстанымы тәріздес. Себебі, олардың өкілдері: «Ақылдың жақсы деп танығанын жасауға міндеттісің. Ақылдың жаман деп танығанынан алыс болуға тиістісің» деп пайымдайтын. Имам Мәтуриди болса, бұл мәселеде имам Ағзамның ойларына жүгінді. Бұл тұрғыда ол: «Ақыл бір нәрсенің жақсы немесе жаман болғанын анықтаған болса да, амал ету үшін үкімді Алла береді. Сондықтан, ақыл діни жауапкершілік мәселесінде кемелді емес. Себебі, діни мәселелердің төресі Аллаһ болып табылады» деді. Ал, имам әшғари: «Жақсы мен жаманды тек Аллаһтың үкімі айырып бере алады. Сондықтан, жамандық пен жақсылықты шариғатпен ғана бағамдауға болады» деп ұқты [17, 340 б.].

Сондай-ақ фиқһ ілімін жетік түсіндіретін мынадай кітаптары бар: «Китабу Мәһази-ш Шарай фи Усули-д-дин», «Китабу Мәһази-ш Шарай фи Усули-л фиқһ», «Китабу-л Жәдал фи усули-л фиқһ», «Китабу-л Усул» немесе «Усулу-л фиқһ» және «әт-Тәһзиб фи Шәрхи-л Жамии-с Сағир».

Ал кәлам ғылымына қатысты еңбектері: «Китабу-т Таухид» (таухид - Алланы бір деп тану кітабы), «Китабу-л - мақалат» (мақалалар кітабы), «Китабу-р әр-Рәдду әла-л Карамита»
(Карамиттерге қарсы жауап), «Китабу-р Рәдд әла-л Усули-л Карамита» (Карамиттердің әдістемесіне қарсы жауап), «Рәдду-л усули-л хамса ли әби Мухаммад әл-Баһили» (әбу Мухаммад әлБаһилидің «Бес негіз (принцип)» атты кітабына қарсы жауап), «Китабу-л рәдди әуаилил-әдилла ли-л Каъби» (Кағбидің «Дәлелдердің әуелгісі» атты еңбегіне қарсы жауап кітабы), «Китабу рәдди тахзиби-л жәдал ли-л Каъби» (Кағбидің «Тартысты түзету» атты еңбегіне қарсы жауап кітабы), «Рәдду китаб уаиди-л фуссақ ли-л Каъби» (Кағбидің «Пасықтардың барар орны» атты кітабына қарсы жауап), «Рәдду Китаби-л Имәма ли Бадир Рауафид» (Бадир Рауафидтің имамдық кітабына қарсы жауап), «Китабу бәяни уәһми-л - муътазилә» (Мұғтазилердің қиялын баяндау кітабы).

Мәтуридидің ақидаға байланысты сақталған кітабы - «Китабу-т Таухид». Мәтуриди өз еңбектерінде тек мутауатир болып танылған хадистерді қолданған.

Мәтуридидің қай жерде білім алғаны белгісіз болғанымен, ғылымда жеткен жетістіктеріне қарап, оның білімі жетік әрі жоғары деп бағаланды. Оның тәлімгері әбу Насыр әл-Ийази «Мәтуриди өзінің және кейінгі заманның ерекше адамы болды. Ол дінді дұрыс түсінікке алып келген, ғалымдар арасында шүбәсіз абыройға ие тұлға болды. Құранның қиын жерлерін түсіндіріп, дінді жалғандықтан сақтады және діндегі тыйым мен рұқсат етілген мәселелерді айқындады» деп, айтып кеткен. Осылайша, Имам әл-Мәтуриди ислам дінінің сенімін жақтап, адасушылармен күрескен ұлы тұлғалардың бірі болды.

\section{Әдебиеттер}

1 Ибн Кәсир. Бидая уән ниһая. - Бейрут: Мәктабатул Мәариф, 1978. - Т.1. - 800 б.

2 Қалмахан Е.С. Асылдың сынығы имам Мәтуриди. - Астана, 2014. - 36 б.

3 Политическая история исламского мира // [Элект. Ресурс: .]

4 Хасан Ибрахим.Тарих әл-Исламия. Т.2. - Каир, 2002. - 387 б.

5 Wilferd Madelung çev. S.Kutlu. Horasan ve Mâverâünnehir'de İlk Mürcie ve Hanefiliğin Yayıllş̧ı//İmam Maturidi ve Maturidilik. - Ankara, 2007. - 250 p.

6 әл-Худри. Мухадарат тарих әл-умам әл-Исламия дәула әл-Аббасия. - Бейрут, 2006. - 554 б.

7 Мырзабеков М.М. Матуриди ілімінің қалыптасу алғышарттары және әбу Мансур әл-Матуридидің өмір сүрген ортасы // ҚазҰУ Хабаршысы. Философия сериясы. Мәдениеттану сериясы. Саясаттану сериясы. - 2015. - №4 (53). - 75-83 бб.

8 Kalaycı M. Tarihi Süreçte Eşarilik-Maturidilik İliş̧kisi. - Ankara, 2011. - 384 p.

9 Исахан М. Имам Матуриди ақидасы // [Элект. Ресурс: http://e-islam.kz/islam/ishki-kategoriyalar/aqida/maturidi/ item/218-eislam.]

10 әбу Абдуллах Мұхаммад әл-Мақдиси. Ахсанул тақасим фи марифатул ақалим. - Каир, 1991. - 407 б.

11 әбу әл-Аббас Ахмад. Уафиятул ағян. - Т.5. - Бейрут: Дар аль-хадис, 1977. Т.1. - Б. 159-160.

12 Korkmaz S. İmam Ebu Mansur el-Maturidi'nin Hayatı ve Eserleri // Dini Araştırmalar, Mayıs-Ağustos. - 2001. - 89-119 ss.

13 Құран кәрім. Мағыналары мен түсіндірмелерінің тәфсірінің аудармасы. - Алматы, 2013. - 776 б.

14 Ak A. Maturidi kaynaklarla Maturidi ve Maturidilik. - Ankara, 2006. - 355 p.

15 Мухаммад Халил ал-Нуайхи. Ал-Уасид имам Матуриди. - Амман: Дару ән-нур, 2013. - 336 б. 
16 Абдурахман ибн Мухаммад ибн Халдун. Муқаддима (ауд: Закир Кадири Уған). - Стамбул, 1990. - Т.2. - 850 б.

17 Тажуддин Субки. Матуридинин ақида рисәлеси ве шархы (дай: С.Эпрем). - Стамбул, 2000. - 347 б.

\section{References}

1 Ibn Kasir. Bidaya uən Nihaya. - Bejrut: Maktabatul Maarif, 1978. - T.1. - 800 b.

2 Қalmaxan E.S. Asy'ldy'n sy'ny'gy' imam Maturidi. - Astana, 2014. - 36 b.

3 Politicheskaya istoriya islamskogo mira // [E'lekt. Resurs: http://www.runivers. ru/doc/isl/index.php?IBLOCK ID $=43 \&$ SECTION_ID $=269$.]

4 Xasan Ibraxim.Tarix al-Islamiya. T.2. - Kair, 2002. - 387 b.

5 Wilferd Madelung çev. S.Kutlu. Horasan ve Mâverâünnehir'de İlk Mürcie ve Hanefiliğin Yayıllış//İmam Maturidi ve Maturidilik. - Ankara, 2007. - 250 p.

6 Al-Xudri. Muxadarat tarix al-umam al-Islamiya dəula əl-Abbasiya. - Bejrut, 2006. - 554 b.

7 My'rzabekov M.M. Maturidi iliminiң kaly'ptasu algy'sharttary' zhəne Abu Mansur al-Maturididin emir syrgen ortasy' // KazUU Xabarshy’sy’. Filosofiya seriyasy’. Madeniettanu seriyasy’. Sayasattanu seriyasy’. - 2015. - №4 (53). - 75-83 bb.

8 Kalaycı M. Tarihi Süreçte Eşarilik-Maturidilik İliş̧isi. - Ankara, 2011. - 384 p.

9 Isaxan M. Imam Maturidi ақidasy' // [E’lekt. Resurs: http://e-islam.kz/islam/ishki-kategoriyalar/aqida/maturidi/item/218eislam.]

10 Abu Abdullax Mұxammad əl-Maқdisi. Axsanul takasim fi marifatul akalim. - Kair, 1991. - 407 b.

11 Abu al-Abbas Axmad. Uafiyatul aғyan. - T.5. - Bejrut: Dar al'-xadis, 1977. T.1. - B. 159-160.

12 Korkmaz S. İmam Ebu Mansur el-Maturidi'nin Hayatı ve Eserleri // Dini Araştırmalar, Mayıs-Ağustos. - 2001. - 89-119 ss.

13 Kyran kərim. Magy'nalary' men tysindirmelerinin tafsirinin audarmasy'. - Almaty', 2013. - 776 b.

14 Ak A. Maturidi kaynaklarla Maturidi ve Maturidilik. - Ankara, 2006. - 355 p.

15 Muxammad Xalil al-Nuajxi. Al-Uasid imam Maturidi. - Amman: Daru ən-nur, 2013. - 336 b.

16 Abduraxman ibn Muxammad ibn Xaldun. Mukaddima (aud: Zakir Kadiri Ugan). - Stambul, 1990. - T.2 - 850 b.

17 Tazhuddin Subki. Maturidinin akida risalesi ve sharxy' (daj: S.E’prem). - Stambul, 2000 - 347 b. 